\title{
LA LITERATURA COMO MÍMESIS. APUNTES PARA LA HISTORIA DE UN MALENTENDIDO
}

En los últimos decenios se ha puesto muy en boga, en el terreno de los estudios literarios, invocar la autoridad de Platón o de Aristóteles para demostrar la validez 'eterna' de una teoría $-\mathrm{y}$, consecuentemente, la imposibilidad de cualquier planteo realmente novedoso- 0 , por el contrario, achacar a ambos filósofos la persistencia de confusiones conceptuales e incluso de posiciones dogmáticas a lo largo de siglos de reflexión sobre la literatura.

En estas páginas me propongo examinar el sentido de una familia de términos técnicos muy utilizada por ambos: mimesis, mimetizar, mimético, etcétera, con el doble fin de despejar tanto objeciones como actitudes apologéticas basadas en equívocos y de señalar la productividad y la importancia de esas nociones para el desarrollo de la ciencia literaria actual

Miméisthai ("mimetizar") designa originariamente $-\mathrm{y}$ el sentido primigenio del nombre griego debió jugar un rol considerable en su adopción como tecnicismo filosófico y teórico-literario- una acción cuya función exclusiva es evocar otra acción con la que guarda una relación de analogía. Caso típico es, por ejemplo, el de un individuo que en un ritual religioso destinado a conjurar a las divinidades de la fertilidad efectúa una serie de movimientos similares a los de un agricultor en trance de arrojar la simiente a los surcos. Tal individuo no siembra sino mimetiza el sembrar. Retengamos desde ya un aspecto de esta actividad que tiene especial relevancia en el campo de las artes: el objeto de la mímesis -el original o el modelo en el sentido no científico del término- puede ser, en el caso señalado, la acción particular, única en su facticidad, de un agricultor particular, igualmente único en su facticidad, pero no tiene por 
qué ser necesariamente así y que de hecho suele no ser así: El objeto de la mimesis puede ser también una clase de acciones correspondiente a una clase de individuos.

Cuando se habla de modelo en el sentido mencionado suele pensarse en un individuo concreto, casi nunca en una abstracción. Se supone que el modélo de una naturaleza muerta, para mencionầ un émplópictórico, debe ser un determinado plato con frutas quefelopintor tuvo ante sus ojos y no aquella "cierta ldea"densumente que Rafael decía retratar.

La noción aristóélica de minnesis fimplica el presupuesto contrario: el carácter genérico aépobjeto de la mímesis artística $y$, en partịula ra de la mimes poética. El no reconocimiento de este rasgowsustancial ha dado pie, como veremos en seguida, a muchos malentendidos y objeciones descaminadas que reaparecentperiódicamente en algunos de los más autorizados críticos de nuestros días.

Mimetizar es para Aristóteles el quehacer específico del artista, el que lo define comotaly el que permite reconocer, más allá de las diferencias en $10 s$ medios, objetos y maneras de la mímesis, el vinculosprofundogue mantiene coherentemente unidas las más diyérsa mañúnestaciones artisticas. El pintor que pinta un paisaje o un plato de frutas, el escultor que da forma a un lánzador de, discos, el poeta que imagina y registra un discursostugro es el suyo, el bailarín o el músico que con movimientos corporales o los sonidos de un instrumento evocanoondutas o emociones, mimetizan por igual.

En oposición con Platón, quịen en el libro $\mathrm{x}$ de La República sostenía que los artesanos mimetizaban las ideas eternas de las cosas y los artiștas mimetizaban las mimetizaciones de los artesanos, Aristóteles entiende que el carpintero que fabrica una silla se limita a producir un objeto que noses representación de un ente ideal, sino lisa y llanamente uña silla determinada. Si ésta se reconoce como tal no es por el hecho de ser reproducción de la idea de silla sino pórque la forma de silla —que sólo puede existir en las múltiples sillas concretas- se realiza en una materia particular. A Ia 
inversa, quien pinta o esculpe una silla no hace un objeto sino la mímesis de un objeto, esto es, lo re-presenta, reproduce la actualización de su forma en un medio distinto de aquél en el que se actualiza la forma de silla para dar lugar a una silla-objeto.

Si bien Aristóteles no se pronuncia con claridad sobre cuál sea el objeto especifico de la mímesis en las artes plásticas, es, por el contrario, bien explícito en lo que concierne a la música, la danza y la poesía, que aparecen englobadas bajo el término póiesis, utilizado por él tanto en este sentido amplio cuanto en el más estrecho de arte verbal. En este último terreno el objeto de la mímesis está constituido, como lo puntualiza repetidas veces, por acciones humanas $y$, secundariamente, por los caracteres que ejecutan dichas acciones.

Ahora bien, puesto que al referirse a la poesía trágica -que dentro de su concepción evolucionista de la historia literaria representa a la poesía por antonomasia- señala que el objeto de la mímesis poética es lo que podria acaecer (Poética, rx), resulta a primera vista justificado suponer que la noción misma de mímesis está confinada a los límites de uno de los tantos metatextos históricos (preceptivos, tratados teóricos descriptivo-normativos, artículos críticos, etcétera) dentro de los cuales el sistema de la literatura se autodefine como tal en un ininterrumpido proceso de cambio (Cf. Lotman 1976, 344-346). Dicho de otro modo: despejada del contexto amplio de la Poética en su totalidad, la caracterización generalizadora de la poesía como mímesis de posibles acciones tiene todo el aspecto de una definición normativa cuya validez, como la de todo enunciado normativo, sería equivalente a la de cualquier otra definición elaborada en el interior de cualquiera de los metatextos literarios identificables en el espacio y en el tiempo.

Es en ese supuesto que se le ha reprochado frecuentemente a la Poética aristotélica -en particular en este sigloel fundarse en postulados no por más sutiles menos totalitarios que los platónicos, que tendrían por finalidad subordinar la creación artística a la noción de realidad dominante 
en el conjunto social, sofocar cualquier intento individual de cuestionamiento de los patrones cognoscitivos generales y afianzar, mediante una repetición servil, la visión estereotipada del mundo en que se sustenta el orden constituido.

El arte propugnado por Antistóteles, la mímesis de acciones posibles cuya función es, como lo precisa âbrupta y telegráficamente el célebre capítulo on provocar en el receptor la catarsis de afectos elementales, constituiría, desde esta perspectiva, una copia, una mera reproducción de lo que una comunidad histórica expentinente como realidad, cuyo sentido primordial sería proporchonar un ersatz, un sustituto ilusorio para la satisfacción de 16 s sentidos y los instintos humanos No mucho más qué ế nuneco -el remedo de padre, madre o hermano- en 61 que el niño desfoga jugando sus amores y su odios (Cf Adoono 1970,354 y passim).

Un persuasivo ejemplo de póetticanantiaristotélica, fundada en parte en la estética détAdorno y del poeta y teórico alemán Siegfried J. Schmidt, sêtalia a en el ensayo del poeta y crítico literario portugués Aibetto Pimenta $O$ silencio dos poetas (Pimenta 1978). En el se sostiene la tesis cle la existencia, a través de todas lasepocas de dos formas de poesía (y de arte en generaly»unàn pósía "poetológicả, supuestamente fundada en las normas âristotélicas, que sería expresión de un conocimiento ded wnundo obtenido a través de categorías conceptuales preexistentes; y una poesía propiamente "estética", que seratexwicusión de un conocimiento individual, directo, concretor no mediatizado por ninguna clasificación apriorístíca Bstar segunda forma de poesía partiría del rechazo dêtartengua en su carácter de sistema modelizador de la teâlidad se empeñaría en transformar $e$ incluso destruir los signos lingüústicos convencionales para articular, a través de esa transfórmación $\% / 0$ de esa destrucción, un modo inmediato y personal de aprehensión y representación del mundo.

Respecto de esta tesis me atrevo a arriesgar que, contra lo que muchos estetas modernos suponen, Aristóteles no sólo la habría suscripto sino que, además, habría identifís. cado la segunda forma de poesía con su propia noción de 
póiesis. Sus reflexiones sobre los medios de expresión propios de la poesía en el capítulo xxir de la Poética y las numerosas observaciones diseminadas a lo largo de casi todo el tercer libro de la Retórica sobre los rasgos distintivos de la elocución poética en oposición a la oratoria, permiten afirmar que Aristóteles no estaba describiendo ni, mucho menos, erigiendo en canon una poesía que subordinara la creatividad cognoscitiva y expresiva del artista a la necesidad de comunicar mensajes comprensibles, basados en un código conocido y en una clasificación apriorística de la realidad. Su exaltación de lo "extraño" (xenikón) que, como ya lo señalé en otra oportunidad (Reisz de Rivarola 1977), anticipa la noción de "extrañamiento" (ostranenie) de los formalistas rusos, y su tendencia a privilegiar la metáfora respecto de las demás figuras por ser el medio de expresión más apto para extrañar, sorprender y transmitir un conocimiento nuevo, muestran a las claras que la elocución poética no era para él el resultado de un compromiso entre necesidades individuales y sociales ni un simple medio entre los extremos de una ramplona inteligibilidad y un refinado hermetismo.

La teoría aristotélica de la metáfora, que incluye una caracterización de las metáforas específicamente poéticas, hace particular hincapié en dos aspectos que hablan a favor de una concepción de poesía que bien puede calificarse de "estética" en el sentido técnico que adquiere este término a partir de Baumgarten, quien por primera vez asoció explicita y sistemáticamente la producción de arte cọn una teoría del conocimiento sensitivo. Esos dos aspectos, sobre los que podrían multiplicarse las citas, son los siguientes:

1) Metaforizar bien es algo que no se puede aprender de nadie, ya que se trata de percibir y expresar una semejanza, hasta entonces oculta, entre dos objetos ( $C f$. Poética, capítulo xxII, 1459 a 4-8; Retórica, L. III, capítulo I1, 1412 a 11-15 y L. IIr, capítulo 2, 1405 a 8-10).

2) Interpretar una metáfora supone la superación de una 
confusión inicial y la placentera sorpresa de cö-descubur la semejanza descubierta por el creador (Gf. Relórica, L. III, capítulo 10,1410 b $10-27$ y L. Inf capítulo $\mathrm{ll}$, 1412 a $19-26)$.

Estas tesis, aun formuladas en en sintética versión que acabo de ofrecer, testimonian. siffictentemente que la obra de arte literaria no es yista como el mero resultado de ha aplicación de una técnica ni por consiguiente, como producto de una aprehensión lutinaria de dos datos de la experiencia. El implícito reconouniento de que el verdacero poeta no percibe el mundo-a traves dẹl filtro preclasificador del código lingüustico manejado por el conjunto social sino que más bien sè ye forzado a tanstormar ese código para poder expresar su visión, petsonal, está en perfecta consonancia con dos concepciones a primera vista tan extrañas e incluso contradictorias como, a) una mímesis cuyo objeto no es un individuo particular, efectivamente existente, sino una posibilidad de individuo y b una mimesis embellecedora o afeadora, que sobre labose de cierto objeto - - existente o meramente posible construye un nuevo objeto, mejor o peor que aquél.

La primera de estas concepciones aparece cuidladosamente fundamentada en el mencionado gapitulo $\mathrm{Ix}$ de la Poética, en el que Aristóteles marcan ho ronteras entre poesía $e$ historia $y$, al hacerlo, sienta a basespara una teoría de la ficción literaria (Cf. Teisz de Rivarotogy 1979).

La seguncla de ellas está claranivente expuesta en el capítulo II, donde se afirma que todos 10 s aitistas -incluidos los artistas plásticos mimetizan carteres superiores, in feriores o semejantes a lo que sueten sent tos hombres. Comó elemento de comparación Aristóteles usa los términos "nosotros" o "los de ahora", con los cuales no alude, sin embargo, a individuos concretos sino a una clașe definible por un conjunto de rasgos comunes a los seres humanos en general. Al sostener que la mímesis trágica se caracteriza, al revés que la comedia, por mimetizar caracteres superiores, sugiere que el poeta trágico elalora un modelo artístico de 
hombre que a su vez guarda cierta relación analógica con un modelo de hombre que forma parte de la noción de realidad, históricamente condicionada, de una determinada comunidad cultural.

En la reflexión precedente he utilizado por primera vez el término modelo en el sentido en que se lo usa en teoría de la ciencia y, a partir de ella, en el ámbito de la semiótica. Semejante desplazamiento conceptual no es causal ni arbitrario. Con él quiero significar que la noción aristotélica de mímesis que, como se vio, resulta contradictoria - si no incomprensible - si se la quiere conmutar por las de imitación o copia, así como la definición de poesía como mímesis de acciones y caracteres, quedan notablemente iluminadas si se las correlaciona como las modernas categorías de modelización y sistema modelizador que Yuri Lotman ha aplicado tan eficazmente al examen de los sistemas semiológicos artisticos.

Lotman considera que todos los lenguajes - tanto los naturales como los artificiales-cumplen no sólo una función comunicativa sino también de modelización en la medida en que cualquier sistema de designación refleja cierta idea clasificatoria de lo que designa, es decir, propone una cierta representación -forzosamente reductora y parcial-D de la realidad designada. Dentro de esta concepción las lenguas naturales ocupan el lugar del sistema modelizador por excelencia, de aquel que organiza todos los procesos cognoscitivos. De ahí que Lotman lo llame primario y que caracterice a los sistemas artísticos - a la par del mito o de la religión- como modelizadorés secundarios en el supuesto de que funcionan a modo de lengua lo que, en el caso especial de la literatura implica además que servirse de la lengua como material (Lotman 1978, 17-36).

Sobre la base de los modelos del mundo elaborados por la conciencia del hombre (que es, para Lotman, una conciencia lingüística) cada cultura y cada época elaboran modelos artísticos del mundo que se superponen a aquéllos y que son tan generales como aquéllos. El creador literario propone, en cambio, a través de sus textos, un modelo par- 
ticular y subjetivo, que se funda tanto en un código lingüístico como en un código artístico determinados, que es inseparable de la estructura de cada texto y que inchye no sólo la representación de ciertos objetos -realmente existentes o sólo pensables- sino también la proyección de la estructura de la conciencia que percibe esos objetos ( $C f$. Lotman 1972, 38).

Cuando Aristóteles sostiene que la póesía -como todas las artes - es mímesis, cuando ubica el objeto de la mímesis trágica en el ámbito de las acciones y los caracteres posibles a la par que admite que el objeto deja mímesis épica es no sólo lo posible sino también lo imposible que convence (Poética, capítulo xxiv, 1460 a $26-27$ ) y cuando, finalmente, señala diferencias fundamentales entre la elocución poética y la retórica así como entre los diferentes tipos de elocución poética en conformidad con los diyeresos géneros literarios, alude a los mismos rasgos que, en la opinión de Lotman, caracterizan a la obra literaria. Con mímesis queda implícitamente aludido el carácter modelizadorde todo sistema artístico. Con el reconocimiento de la existencia de un conjunto de normas que regulan la construcción del mundo ficcional en cada género literario y de un subcódigo-lingüístico igualmente propio de cada género, queda abierto el camino para el reconocimiento de la literatura cowo un sistema modelizador secundario y del texto literatio como el producto de una doble codificación: según el código de la lengua (del sistema modelizador primario) y seônu una compleja jerarquía de códigos artísticos variables para cada época, género, estilo, etcétera (los del sistema modéliżador secundario).

De todo lo dicho se desprende quenii la definición del arte como mímesis ni la definición de póicsis en sentido amplio (literatura, música y danza) como mímesis de acciones y caracteres ni, por último, la definición de póiesis en sentido estrecho (fundamentalmente poesía trágica) como mimesis de acciones y caracteres posibles, se ubican en el nivel correspondiente a una reflexión metaliteraria de tipo preceptiyo: Un examen atento de los contextos en que aparecen todas estas definiciones permite localizarlas en un nivel superior: el 
correspondiente a una teoría cuya tarea no es sentar normas ni evaluar las obras literarias conforme a determinados sistemas normativos ni tampoco evaluar los sistemas normativos mismos, sino describir y explicar un conjunto de fenómenos entre los que se incluyen precisamente las definiciones y los sistemas normativos así como los criterios de evaluación emanados de ellos (Cf. Mignolo 1978, 44-45).

La afirmación precedente no implica, por cierto, que la Poética aristotélica en conjunto se ubique en el plano de la teoría en el sentido que acabo de precisar. Es un hecho bien sabido que ya desde el primer párrafo se manifiesta en ella la tendencia a combinar constantemente $\rightarrow$ y a veces confundir- una perspectiva descriptiva (que bien podría calificarse de estructuralista) con la preocupación por fijar paradigmas de buena poesía a los que se les atribuye validez universal y eterna. Uno de los resultados más notorios de esta tendencia sincretizadora es la identificación de la estructura de la poesía trágica con la estructura de la tragedia del siglo $v$ a.C. $y$, en particular, con la de la tragedia sofoclea, que representa para Aristóteles una cumbre jamás igualada. Otro resultado de esa mezcla de ópticas -especialmente relevante para nuestra reflexión- es el erigir la mímesis de acciones posibles -que, como el propio Aristóteles lo admite implícitamente, designa un tipo literario ficcional entre otros- en fómula definidora de la poesía en general, por el hecho de corresponder a un género literario que Aristóteles ubicaba en el punto terminal de un largo proceso de perfeccionamiento.

Pródiga fuente de equívocos $\mathrm{y}$, por ello mismo, de objeciones desacertadas es asimismo la teoría platónico-aristotélica de la división de la poesía en géneros, dentro de la cual el par terminológico mimesis-diégesis juega un rol fundamental. En este punto Aristóteles sigue dócilmente la propuesta clasificatoria de su maestro, limitándose a modificar la nomenclatura en consonancia con sus propios planteos sobre la naturaleza mimética de las artes. Aristóteles es más consecuente que Platón en la utilización de aquellas expresiones que él adopta como términos técnicos. En efecto, en 
la Poética, la familia léxica mimesis, nimetizar, mimético, etcétera, alude invariablemente al carácter modelizador -no simplemente imitativo ni, mucho menos, imperfectamente imitativo según la teoría platónica-.- de los sistemas artísticos. En Platón, en cambio, esa misma familia cubre un campo semántico bastante ampliony óde contomos difusos, que incluye conceptos como "imitaciôn "y temulación", "repetición en un medio distinto delloríginal", "reproducción engañosa", "reflejo", "espejismo" "côpia de copias (alejada del original en dos grados)", etcétera Gl último de los conceptos mencionados es el dominante en el 1 bro x de La República, en el que todas las artes son censúradas por estar aún más alejadas del mundo de las ideas que a poseudo-realidad, ya en sí misma ilusoria, del mundo de lós sentidos. En el libro III usa, en cambio, el término mímêsis con un significadó técnico-literario para designar con ề una de las modalidades de presentación de sucesos Allí define á la poesía como "diégesis de cosas pasadas, presentes o futuras" (392 d 3) debiéndose entender por diégesis no simplemente "relato", como hoy se acostumbra, sino un tconcepto englobante de aquél, tal vez traduciblée pór sexposiciön", "presentación" o "construcción imitátiva", que abarca tanto una modalidad narrativa como unầ modalidad descriptiva. Platón llama, por tanto, diégesis a lo que Aristóteles llamará mimesis de acciones y distingue dentiro de ella, a) una diégesis simple, que corresponde al actiall "concepto de "relato", en la que las acciones de los personajes son referidas por el poeta; b) una diégesis a través de ta mímesis, en la que las acciones, tanto verbales como no. verbales, son directamente ejecutadas por los personajes sin mediación del poeta; y c) una diégesis mixla, en la que alternan el relato de acciones con la presentación inmediata de acciones verbales ejecutadas por los personajes (los llamados "discursos directos"): La primera forma es identificada con el ditirambo, la segunda con la tragedia y la comedia y la tercera con la epopeya (República, Libro III, vi-vir, 392 d - 394 c 5 ).

En el capítulo in de la Poética Aristótelés adopta esta 
delimitación con algunas leves variantes, como surge del siguiente pasaje:

En efecto, con los mismos medios es posible mimetizar las mismas cosas unas veces narrándolas (ya convirtiéndose en otra cosa, como hace Homero, ya como uno mismo y sin cambiar), o bien presentando a todos los mimetizados como obrando $y$ en acción (1448 a 20-24).*

Las diferencias más notorias -aparte de las meramente terminológicas- radican en que Aristóteles subsume la diégesis simple (el relato puro) y la diégesis mixta de Platón en una categoría general narrativa que se contrapone al drama, $y$ en que no ejemplifica con el ditirambo ni con ninguna forma literaria determinada la variante del relato puro.

Me he detenido con alguna morosidad en los textos clásicos para que la objeción que debo hacerle a uno de los maestros de la narratología moderna, Harald Weinrich, no parezca superficial o arbitraria. En un trabajo de reciente data, "Los tiempos y las personas" (Weinrich 1978), intenta rendir a Platón y Aristóteles un homenaje que, lamentablemente, se funda en una distorsión de las ideas de ambos sobre los géneros. Señala allí con razón que dichas ideas constituyen un precedente fundamental para la moderna oposición entre lo no narrativo y. lo narrativo pero basa este reconocimiento en dos argumentos que implican una visión anacrónica de los sistemas teórico-literarios de ambos filósofos. Uno de ellos es que la oposición entre lo mimético y lo no mimético (en el sistema platónico) o entre lo mimético directo y lo mimético indirecto (en el sistema aristotélico) les habría permitido a ambos distinguir dos géneros polares puros, el de la poesía dramática y el de la poesía lírica, y un género mixto, el de la poesía épica (Weinrich 1978, 25).

Semejante aserto es el resultado del desconocimiento de los diversos estadios que integran el proceso de formación

* Las traducciones de los textos de Aristóteles y Platón son mías. 
de la conciencia de clases de textos literarios en el mundo griego antiguo. Ni Platón ni Aristóteles hablaron jamás de "poesía lírica." o de "poeta lírico". No podían hacerlo pues ninguno de los dos reconocía un tercer gran género que, sin ser mezcla de narrativa y drama, se opusiera igualmente a ambos. Por otra parte, en caso dé que lo hubieran reconocido, no do habrían llamado poesiálítica sino mélica (de melos: "canto"), ya que éste era el wumico término usual en su época para designar cualquier trpo de poesia destinada a ser cantada. En, este rasgo, el único común a muchas y variadas formas versificadas no subsumibles en el drama ni en la epopeya, se apoyarían posteriormente los gramáticos alejandrinos - $\tan$ dados al afán catalogador- para clelimitar una tercera gran categoría poética, equipolente de la poesía dramática y épica, a la quépétóutizarían con el término lírica (derivado del nombre de tho de los instrumentos más usados para acompañar nuusicalmente esas composiciones).

El anacronismo de Weinrich se explica tal vez por el hecho de que Platón, a diferencia de Aristóteles, ejemplifica la diégesis simple (la forma no minética de su sistema) con el ditirambo, que era precisamente wno de los tantos especímenes de poesía-canción que los adejandrinos englobarían más tarde en el género lírico. Peroptatón no lo menciona por su carácter musical ni porque pósyera ninguno de los rasgos que la conciencia literaria moderna reconoce como líricos (tales como estatismo, subjetivismo, tendencia monologizadora, etcétera) sino por el simple hecho de ser puramente narrativo. En efecto, si biên no se conoce ningún ejemplar de ditirambo primigenio y los pocos ditirambos tardíos que se conservan (por ej. "Los persas" de Timoteo) muestran una evolución hacia el predominio total de la música sobre el texto así como elementos dialógico-dramáticos; hay testimonios suficientes de que este tipo de composición, que fue originalmente una canción cultural consagrada a Dionysos, se volvió eminentemente narrativa y de contenido heroico no dionisiaco a raíz de las innovaciones introducidas por el legendario Arión hacia el 600 a.C. Podemos, pues, 
representarnos el ditirambo a que alude Platón como una canción coral destinada a una gran masa de voces masculinas, que relataba las hazañas y padecimientos de algún héroe mítico en el estilo indirecto tan exactamente descripto e ilustrado por el propio filósofo con su versión no mimética del comienzo de La Ilíada (República, Libro In, vr, 393 d $3-394$ b).

El otro argumento anacronístico de Weinrich al que me referí más arriba consiste en asignar al problema de las personas gramaticales un lugar central dentro de la teoría platónico-aristotélica de las tres modalidades de poesía. El siguiente pasaje testimonia más de una confusión sobre lo que ambos filósofos estaban en condiciones de decir:

Ahora bien, el criterio de esta distinción está basado en el capítulo de las personas gramaticales que corresponde a la gramática. Es así que pudieron afirmar que cuando el poeta lírico dice "yo" es posible saber que es él mismo quien habla; en consecuencia, el poeta lírico no es imitador. Mientras que si, por el contrario, es el poeta dramático el que dice "yo", éste imita a alguien, apoderándose así de su rol comunicativo (Weinrich 1978, 25).

No vale la pena insistir en el hecho de que ni Platón.ni Aristóteles tenían la noción de "poeta lírico" pero, aun prescindiendo de esta indebida atribución, se hace preciso puntualizar que jamás tematizaron el uso de las personas gramaticales en relación con los géneros literarios reconocidos en su época como tales. Es más: sorprende comprobar que ninguno de ambos se ocupó de preguntarse qué ocurre cuando el poeta épico invoca a la Musa para que lo inspire, refiriéndose a sí mismo en su calidad de poeta-narrador. El que no mezclaran aquí el problema de las personas gramaticales me parece, con todo, un acierto: como si hubieran intuido, anticipándose en muchos siglos a las más recientes reflexiones sobre el tema, que el único criterio decisivo para distinguir tipos de discursos no es que el que habla diga "yo", "tú" o "él" sino que haya o no relación de identidad entre el sujeto del enunciado y el sujeto de la enunciación 
por un lado, y entre la fuente del discurso y el creador literario, por el otro. Es este aspecto fundamental - el de los roles asumidos por el productor del discurso- el que subrayan ambos filósofos cuando contraponen narrativa y drama y, sobre todo, cuando adjudican un stalus especial, dentro de esta oposición categoriál a los poemas homéricos. La siguiente caracterización que Platón hace del comienzo de La Iliada es suficientemente èlociente al respecto:

Entonces sabes que hasta estos veroos ty a todos los aqueos, y. particularmente a los dos Atridas, caudillos de puebios, así Ies suplicaba" es el poeta el que dablay no trata de llevar nuestros pensamientos a otra parte cono si hablara otro en lugar de él. Pero inmediatainchte despues habla como si fuera Crises y se esfuerza al máximio por darnos la impresión de que no es Homero quien hibth sino el anciano sacerdote. Y en esta forma poco más o nienos ha compuesto casi todo el resto de la narración de los sucesos ocurriclos en Ilión, en Itaca y en toda la Odisca. (República; Libro III, vi, 393 a 3393 b 5 ).

Como puede apreciarse, Platón plantea el problema de los diferentes tipos de narración en térinitinos muy próximos a los recientemente propuestos por J: $R$. Searle (Searle 1975) con la diferencia de que no ineurre, como este autor, en la tentación de mezclar electiterio distintivo de los roles discursivos con el de las personas gramaticales (Cf. Reisz de Rivarola 1979, 100-101). Desde la perspectiva de la moderna teoría literaria la única impredision conceptual radica en la identificación del narrador coń el autor, esto es, de la fuente de lenguaje imaginaria de que dimana la narración con el o los individuos históricos ("Homero") que imaginaron y registraron los actos cle habla de esa fuente de len: guaje. En este punto. Aristóteles sigue clócilmente las huéllas de su maestro. Los mismos aciertos y la misma confusión del narrador con el autor caracterizan el pasaje arriba citado de la Poćtica en el que contrapone la narrativa, èn sus dos variedades fundamentales, al diama.

Las reflexiones de Weinrich sobre el aporte de la teoría 
literaria antigua a la narratología desarrollada en los últimos decenios de este siglo, se fundan en parte en un trabajo ya algo viejo de Genette que ha gozado de gran difusión, especialmente en el ámbito hispanoarnericano. Me refiero a "Fronteras del relato", aparecido originariamente en el ya célebre número de la revista Communications dedicado al análisis estructural del relato (Genette 1970 [1966]).

En ese artículo Genette exhuma la terminología platónico-aristotélica para señalar tanto los grandes hallazgos como las presuntas omisiones y confusiones de ambos filósofos para lanzar a través de ella una tesis que en su formulación más sintética y provocativa reza: "Mímesis es diégesis" (Genette 1970, 198). Con ello quiere significar que sólo puede hablarse de mímesis en aquellos casos en que un hablante relata acciones ajenas o propias en lugar de ejecutarlas o bien refiere en las formas del estilo indirecto discursos ajenos o propios en lugar de citarlos o pronunciarlos.

Puesto que Genette entiende que la mímesis, en tanto actividad especifica del poeta, consiste en "representar por medios verbales una realidad no verbal $\mathrm{y}$, excepcionalmente, verbal" (ibid. 196) excluye de este ámbito tanto la mímesis escénica —los gestos y movimientos de los actorescomo todas las acciones verbales englobables en la categoría del discurso (en el sentido de Benveniste) por oposición al relato, independientemente de que estén destinadas a la escena o no lo estén. Según Genette tanto los parlamentos de los personajes dramáticos como los discursos directos intercalados en la narración épica no mimetizan nada sino que repiten literalmente un discurso real $\longrightarrow$ si es que ha sido efectivamente pronunciado- o bien — caso el más frecuente- constituyen verbalmente un discurso ficticio. Sólo habria trabajo de mímesis cuando con el lenguaje se busca suscitar en la mente del receptor la imagen de objetos no verbales (por ej. cosas materiales, personas, sucesos, etcétera) o cuando los objetos verbales (los discursos de personajes) aparecen incorporados a la narración, vale decir, transpuestos a otro estilo, modificados, resumidos o, para decirlo en 
los términos de Genette, imperfectamente imitados, ya que él parte del supuesto de que un "discurso no puede imitar perfectamente sino a un discurso perfectamente idéntico" (ibid. 197-198).

Por las mismas razones exoluye del ámbito de la mímesis toda la poesía hoy caracteiráble como lírica, satírica o didáctica, en la que una fuente de lenguaje, en muchos casos identificable con el productor deletexto, pronuncia un discurso asumiéndolo como propio En tel hecho de que ni. Platón ni Aristóteles hicieran ta mento alusión a las muchas formas poéticas griegas de estetpo que ellos no podían desconocer, Genette ve la confirmandonde su tesis, que le permite así separar limpiamente âtretato de todas las demás clases de discurso y, a la vez, dewlos otros clos grandes géneros tradicionalmente admitidos ( adjudicarle como rasgo distintivo els ser la única forma auténtica de mímesis (Cf. $202 \mathrm{ss}$.).

Semejante propuesta no déja deser interesante y sugestiva pero a condición de que no pretenda erigirse en la versión corregida (y correcta) de ta teoría literaria aristotélica. Uno de los principalés reprôthes que se le pueden hacer en este sentido es reductir 1 thoctonn de mimesis a "imitación' o 'representación' dando a a a w yez por sentado que el objeto de la imitación o representación es un individuo particular, con características prefijadas, que está esperando ser debidamente representado. Genette incurre en el mismo error que él achaca indebidamente a una supuesta teoria platónico-aristotélica de la mitáciondectando sostiene que ésta no establece diferencias entive focóon y representación pues para ella el objeto de la fiéción es "un simulacro de realidad, tan trascendente al discurso que lo lleva a cabo como el acontecimiento histórico es exterior al discurso dell historiador o el paisaje representado al cuadro que ló te presenta" (197). Esta objeción, que -insisto se vuelve ur boomerang contra el propio Genétte, nọ es pertinente pará ninguno de los dos filósofos, si bien por razones diametralmente opuestas. A Platón no lo toca pies él no confundes representación con ficción sino ficcionalidad con mentika. 
Y a Aristóteles tampoco, ya que al excluir a la poesía del ámbito propio de la historia - el de lo particular y efectivamente acaecido- y al ubicarla en el terreno de lo general y posible $y$, en casos especiales, hasta de lo imposible, consagra implícitamente a la ficcionalidad como rasgo dịstintivo de la mímesis literaria. Sólo en un sentido muy alto y simplificador puede decirse que esta operación mental equivale a no distinguir representación de ficción.

Pienso que en el curso de toda esta reflexión $y$, en especial, tras la revisión de los contextos en que aparecen estas nociones, ha quedado suficientemente claro que para Aristóteles el objeto de la mímesis poética - y consecuentemente el de la ficción- no es trascendente al discurso que la realiza en la misma medida en que puede serlo un acontecimiento histórico al discurso del historiador.

$\mathrm{Si}$, como se ha visto, lo característico del arte que tiene como medio el lenguaje, el ritmo y la armonía, es que su objeto no es un ente concreto sino una posibilidad y que esa posibilidad a su vez puede ser embellecida o afeada en el proceso mismo de mimetización, entonces es preciso concluir que la mímesis literaria no consiste en representar imitativamente, por medio de los signos convencionales del lenguaje, un objeto que ha sido previamente aprehendido a través del filtro preclasificador del código lingüístico común a un conjunto social, esto es, independiente de y preexistente al trabajo de representación. La mímesis literaria es, antes bien, un complejo proceso de estructuración de los datos procedentes de $u$ acto de conocimiento resultante del rechazo de los conceptos apriorísticos impuestos por la lengua. No se trata, por tanto, de la simple verbalizaciónreproducción de cierto modelo del mundo largamente internalizado, sino de la elaboración de un modelo nuevo, menos general y abstracto que los preexistentes, obtenido en y mediante el proceso de desconstrucción y manipulación del código de la lengua, proceso timoneado por las normas del código literario particular adoptado por el artista.

En conformidad con esta noción de mimesis -y no con la postulada por Genette e indebidanente atribuida a Aris: 
tóteles- no es posible sostener que la única forma auténtica de mímesis sea el relato de acciones no verbales y la transposición de acciones verbales al estilo indirecto. Si uno se ubica en el interior del sistema aristotélico se puede argumentar que así como una tragedia o una epopeya son, descle una perspectiva macroestructural, modelos de posibles acciones (tanto no verbales como verbales), los parlamentos de los personajes dramáticos y los discirsos directos intercalados en el relato épico son modelos de posibles discursos. Lo que lieva a Genette a afirmar que en tales parlamentos y discursos no hay trabajo de mimesis -en el sentido a construcción a partir ce algo sino cita o autogeneración, es el falso supuesto de quebelobjeto de la mímesis es un individuo particular y concreto cuando se parte de la premisa correcta, a saber, quevél objeto en cuestión no es un discurso determinado sino lo que cierto tipo de hombre podría decir en cierto tipo de circunstancias $(C f$. Poética, capítulo Ix), las diferencias entre el objeto y el producto de la mímesis se perfilan conninitidez: son las que se dan entre lo posible y lo fáctico, lo general y lo particular, lo abstracto y lo concreto, la clase y cada uno de los individuos que ostentan los rasgos distintivyós de la clase.

Este mismo razonamiento podria aplicarse a esa multiforme familia de textos poético-musicales que los alejandrinos subsumieron en la categoría de la "lírica" así como esa otra familia - considerada aparte por su petrónámbico y la au-

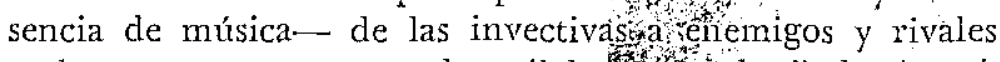
reales o supuestos, como los célebrest yambos" de.Arquíloco. Dejo deliberadamente de lado.el caso de los poemas filosóficos a la manera de un Empédodès y, en general, el de las obras didácticas en verso, pues el mismo Aristóteles los excluye en forma explícita del ámbito de lámesis lis teraria $y$, en consecuencia, del ámbito de la póiesis en sentido restringido, noción que corresponde aproximadamente al moderno concepto de literatura (Ćf. Poética, capítulót) El que Aristóteles niegue la condición de poetas a los autores de tales poemas a la par que indirectamente adjudica. carácter poético a los diálogos de Platón, evidencia una con- 
cepción de lo literario en ciertos aspectos más amplia y en ciertos aspectos más estrecha de la vigente desde los albores de la Grecia clásica hasta hoy. Aristóteles introdujo polémicamente, ya desde el primer capítulo de su Poética, un criterio de demarcación que iba contra todos los hábitos clasificatorios tradicionales y que no logró imponerse ni en su época ni en siglos posteriores. En su opinión no es la presencia o ausencia del verso ni la presencia o ausencia de música acompañante ni el uso de un lenguaje particular lo que distingue fundamentalmente a los textos poéticos -es decir, literarios - sino el ser mímesis de acciones y sólo secundariamente de los caracteres que ejecutan esas acciones.

El llamativo hecho de que Aristóteles no incluyera ni excluyera expresamente de la esfera de la póiesis ninguno de los tipos de textos hoy caracterizables como líricos o satíricos -que él debía forzosamente conocer-, no parece ser indicador de una decisión negativa (la de rotularlos como no literarios), sino, antes bien, de una perplejidad por la resistencia que esos textos ofrecían a ser encasillados dentro de la mímesis de acciones.

En efecto, si se tiene en cuenta que la praxis aristotélica no es una acción cualquiera sino una hecha con la intención de alcanzar un fin determinado $y$, además, condicionada por la estructura psico-moral y los patrones comportamentales habituales en el individuo actuante, resulta claro que los personajes de tragedia o de epopeya realizan tales acciones, como cuando Orestes mata a su madre para vengar a su padre, Edipo busca la verdad que lo conducirá a la ruina o Aquiles se retira de la lucha irritado por la ofensa de Agrmenón. Resulta claro, asimismo, que tales personajes no sólo ejecutan ese tipo específico de acciones sino que también son víctimas o beneficiarios de análogas acciones ajenas, esto es, hacen cosas y les ocurren cosas, todo lo cual configura un entramado de sucesos causalmente conectados entre sí que pueden ser presentados de modo inmediato ante los ojos del espectador, como en el drama, o bien tan sólo referidos, como en la epopeya. Es explicable, entonces, que Aristóteles concentrara toda su atención en estas dos 
formas poéticas en detrimento de todas las demás. $O$, si se quiere expresar esto mismo desde otro ángulo del problema, es natural que extrayera sus criterios olfsificatorios de las dos formas poéticas que más apreciaba. Queda por ver, empero, si esta última circunstancia quita validez general a su definición de poesía $y$ la hace ingresar, contra lo que afirmé al comienzo, al nivel correspondiente a un enunciado normativo.

Cabe preguntarse - y es probable que Aristóteles mismo se lo hàya preguntado, sin hallar una respuesta satisfactoria- en qué medicla un texto como el de la celebérrima oda de Safo en la que una voz describe la suprema intensidad de sus vivencias eróticas a la vista de la cloncella amada y perteneciente al hombre que está gozando de su compañía, se puede considerar como resultado del proceso de mimetización de cierta clase de accioncs.

La respuesta tendrá que ser negativa si se piensa primordialmente en las acciones verbales $y$, sobre todo, no verbales de los héroes trágicos o épicos en las que se manifiesta del modo más abrupto el conflicto entre la decisión provocativa, emanada del ethos, y los límites impuestos por la voluntad divina o por otra voluntad hetmana.

La respuesta podrá, en cambio, ser positiva, si se piensa en las muchas acciones verbales de esos mismos personajes a través de las cuales tan sólo se hace patente cierta contextura psíquica, cierta visión del mundo o ciẹto estado anímico. Dado que los parlamentos con estas características están muy próximos al caso, que parecía tán problemático, de la mencionada oda de Safo y que no parece razonable suponer que Aristóteles no los considerara parte constitutiva de la mímesis de acciones, es posible completar el pensamiento aristotélico allí donde ha quedado lagunoso y res catar la lírica - tal como hoy la entendemos - para incluif la expresamente en el campo de la póiesis. Para ello no es necesario modificar la definición correspondiente sino tan sólo desplazar los acentos haciendo de lo secundario lo principal y viceversa.

No diremos, pucs, que la lírica, como la poesía trágica, 
es mímesis de acciones $y$, en segundo lugar, de los caracteres que ejecutan esas acciones, sino, a la inversa, que es, en primera lnea, mimesis de caracteres que se manifiestan a través de acciones verbales.

Si se tiene en cuenta que el texto lírico no se puede identificar con el discurso del poeta que lo imagina y fija verbalmente sino con el discurso de la fuente de lenguaje instaurada por él para articular por su intermedio vivencias propias y/o ajenas, es lícito definirlo como resultado de un proceso de mimetización que tiene por objeto el posible discurso de un posible carácter que puede estar más o menos próximo al del poeta. El producto de este proceso es un modelo de discurso cuya diferencia con los modelos de discursos más frecuentes en la poesía trágica y épica es que su función básica consiste en poner al descubierto un modelo de vivencias $y$, simultáneamente, un modelo de conciencia sensitiva.

Espero que este recorrido, tal vez algo prolijo, por algunas de las nociones más ricas en consecuencias pero de contomos menos nítidos de la teoría literaria antigua haya servido para remarcar su ininterrumpida vitalidad y para llamar a la vez la atención sobre la necesidad de practicar una cuidadosa exégesis toda vez que se las quiera incorporar al estado actual de la reflexión en torno a los mismos problemas que la ciencia de entonces procuraba dilucidar con ellas.

Universidad Católica del Perú

Susana Reist de Rivarola

\section{BIBLIOGRAFIA}

Tri. W. Adonvo, Asthetische Theorie, Frankfurt am Main, Subrkamp, 1970.

ArIstóteles, Poética (Aristotle, Poetics, ed. D. W. Lucas, Oxford University Press, 1972).

-_. Relórica (Aristotelis, Ars Rheloricn, ed. W. D. Ross, Oxford University Press, 1959).

C. GenetTr, "Fronteras del relato", en R. Barthes et al., Análisis estruclural del relato, Buenos Aires, Tiempo Contemporáneo, 1970 , 
pp. 193-208 (versión original en Communications 8, 1966, pp. 152I63).

Y. M. Lotman, Estructura del texto artistico, Madrid, Istmo, 1978. "The Content and Structure of the Concept of "Literature", PTL, I, núm. 2, 1976, pp. 339-356.

—, Vorlesungen zu einer strukturalen Poetik, Munich, Fink Verlag, 1972.

W. D. Mignolo, Elementos para una teoria del texto literario, Barcelona, Crítica, 1978.

A. Pminta, O siléncio dos poetas, a regrando jogo, Lisboa, 1978.

Platón, República (Platonis, Opera, ed, Tíbunet, Tomus $\mathrm{Ny}_{i}$ Oxford University Press. 1962).

S. Reisz dE Rivarola, "Ficcionalidad, referencia, tipos de ficción literaria”, Lexis ut, núm. 2, 1979, pp.99170.

- - "Predicación metafórica y discurso simbibblico. Hacia una tẹoría

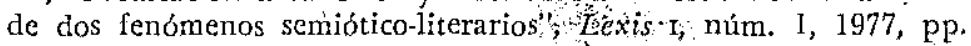
51-99.

J. R. Searle, "The logical status of fictionil discourse", Nezv Literary History VI, núm. 2, 1975, pp. 319-332

H. WeINRICH, "Los tiempos y las personas", dispositio, III, núms. 7.8, 1978, pp. 21-3S. 